\title{
SCOPE OF THE USE OF THE INDIVIDUALS TAX RELIEFS IN THE CZECH REPUBLIC
}

\author{
[Rozsah využívání daňových úlev fyzických osob v ČR] \\ Pavlína Kirschnerová ${ }^{\text {, Jana Janoušková }}{ }^{2}$ \\ ${ }^{1}$ Slezská univerzita, Obchodně podnikatelská fakulta, Univerzitní nám. 1934/3,733 40 Karviná \\ Email:kirschnerova@opf.slu.cz \\ ${ }^{2}$ Slezská univerzita, Obchodně podnikatelská fakulta, Univerzitní nám. 1934/3,733 40 Karviná \\ Email:janouskova@opf.slu.cz
}

\begin{abstract}
The paper focuses on tax relief individuals that are used to support other desirable public policy. They may represent hidden subsidies in the tax system, reducing tax revenue and complications in the administration. Analysis of tax reliefs is complicated because their uniform definition does not exist. They can mean deductions from the tax base (tax allowances), the tax relief or the tax credit, which reduce the actual tax liability. The aim of this paper is to evaluate the scope of use of tax reliefs, which are granted to individuals in the Czech Republic, in the form of non-taxable portion of the tax. Methodically, the research relies on the evaluation of secondary statistical data of the Czech Republic Financial Management and is based on aggregated data from tax returns filed for the years 2005 - 2014, which are statistically processed further.
\end{abstract}

Keywords: individuals, tax, tax allowances, tax reliefs.

JEL classification: H2, D14, E62

Doručeno redakci: 24.11.2016; Recenzováno: 29.11.2016; 12.12.2016; Schváleno k publikování: 1.3.2017

\section{Úvod}

Daňové úlevy jsou jedním z fiskálních nástrojů státu, jejichž prostřednictvím jsou podporovány žádoucí veřejné politiky. Smyslem daňových úlev je za určitých podmínek poskytnout poplatníkům výhodu ve formě nižších daňových odvodů a zároveň ovlivnit chování poplatníka žádoucím směrem. S tím souvisí fakt, že takovéto snížení daně znamená nižší daňové výnosy státu, může představovat skrytou dotaci v daňovém systému a zároveň s sebou nese vyšší administrativní náklady (Pechman 2001). Z těchto důvodů je nutné věnovat daňovým úlevám pozornost a provádět jejich analýzu, což vyplývá i z požadavku Evropské Komise směrnice Rady č. 2011/85/EU ${ }^{1}$ se záměrem následných doporučení pro fiskální politiku.

Analýza daňových úlev je složitá z důvodu neexistence jejich jednotné definice. Daňové úlevy zahrnují slevy na dani, odpočty ze základu daně a daňová osvobození (Janoušková 2012). V odborné literatuře nelze najít jednotu v jejich vymezení. Fookes (2009) za daňové úlevy považuje ty, které mají vyšší cíl, než je naplnění státního rozpočtu. James a Nobes (1999) daňové úlevy specifikují jejich nahraditelností přímým výdajem. Altshuler a Dietz (2006) za daňové úlevy považují jen ty, které snižují základ daně.

Vymezením kritérií daňových úlev se zabýval Surrey (1973) a zkoumal jejich vliv na ekonomický rozvoj. Vymezil kritéria pro identifikaci daňových úlev a popsal metodu ušlých př́ijmů pro jejich kvantifikaci. Na jeho výzkum navazuje řada autorů jako Burman (2013) $\mathrm{s}$ potřebou reformy daně $\mathrm{z}$ př́ijmů $\mathrm{v}$ kontextu nutnosti úprav a omezení nejrůznějších daňových

\footnotetext{
1 Webový portál (c) Evropská unie: Eur - Lex [online]. [vid. 15. řrijna 2016]. Dostupné z: http://eurlex.europa.eu/legal-content/CS/TXT/?uri=CELEX:32011L0085
} 
úlev, což vede k nepřehlednosti a snížení daňové efektivnosti. Faricy a Ellis (2014) poukazují na provázanost veřejné podpory u sociálních programů a programů daňových výdajů. Současná literatura pro kvantifikaci využívá třech základních metod (Polackova, Brixi 2004), a to metodu ušlých př́ijmů, metodu dodatečných př́ijmů a metodu výdajového ekvivalentu. V ČR identifikoval daňové úlevy Jareš (2010) a provedl jejich klasifikaci podle účelu, pro který byly zavedeny. Spolu s Kubátovou (2011) se taktéž věnoval kvantifikaci těchto daňových úlev s využitím výše zmíněných tří přístupů (tj. metodou ušlých př́ijmů, metodou dodatečných příjmů a metodou výdajového ekvivalentu). Ministerstvo financí v roce 2014 poprvé publikovalo Zprávu o daňových úlevách ${ }^{2}$ s odhady jejich celkové výše za roky 2011 a 2012.

Otázkou existence, eliminací či úplným zrušením daňových úlev úzce souvisí i teorie rovné daně, kterou zpracovali koncem 80. let ekonomové Hall a Rabuszka (2007). Podle Čižíka (2008) a Walkera (2006) by cílem zavedení rovné daně mělo být zjednodušení, zefektivnění a zprůhlednění celého daňového systému a to tak, aby nedošlo $\mathrm{k}$ výraznějšímu propadu př́imů státního rozpočtu. Praktickým důsledkem by pak měla být minimalizace celkových nákladů jak pro daňovou správu, tak pro daňové plátce.

\section{Cíl př́íspěvku a metodika zpracování}

Tento prríspěvek je zaměřen na daňové úlevy fyzických osob ve formě odpočtů od základu daně. V českém daňovém právu jsou zavedeny pod pojmem nezdanitelné části základu daně, kdy snižují daňový základ poplatníka a tím i jeho výslednou daňovou povinnost. Do zákona o daních z př́jmů byly implementovány za účelem podpory jiných veřejných politik. Mají formu odpočtu od základu daně. Kromě jejich deskripce je osvětlen způsob, jak jsou tyto možnosti daňovými subjekty využívány. Cílem příspěvku je vyhodnotit rozsah používání nezdanitelných částí ze základu daně daňovými poplatníky a posoudit jejich dopad na státní rozpočet. Metodicky výzkum vychází ze sekundárních statistických dat z let 2005 -2014, poskytovaných Finanční správou ČR, která je zpracovává na základě daňových přiznání. Tato data budou dále statisticky zpracována mírou středních hodnot a následně pomocí syntézy a analogie dojde k jejich vyhodnocení.

\section{Nezdanitelné části základu daně v podmínkách České republiky}

Nezdanitelné části základu daně u fyzických osob jsou pojaty jako odpočty hodnoty darů, výše zaplacených úroků z úvěrů na bydlení, příspěvky na životní pojištění a penzijní připojištění, členské odborové příspěvky a odpočty za zkoušky dalšího vzdělávání. Do zákona o daních z příjmů byly implementovány postupně od roku 1993 a procházejí škálou změn.

Odpočet daru od základu daně je již od roku 1993 jedním z daňových nástrojů, který má podpořit filantropii v ČR. Je tak očekávána finanční podpora neziskových, veřejně prospěšných organizací od soukromého sektoru (Janoušková, Kirschnerová 2015). Uplatňovaná hodnota bezúplatného plnění (daru), která byla poplatníkem poskytnuta neziskovým organizacím, musí přesáhnout $2 \%$ ze základu daně anebo činit alespoň $1000 \mathrm{Kč}$. Od roku $2014 \mathrm{v}$ souladu s podporou donátorství lze v úhrnu odečíst nejvýše $15 \%$ ze základu daně. Maximální hranice tak byla navýšena o 5 procentních bodů. Do tohoto roku bylo možné odečíst nejvýše $10 \%$ ze základu daně.

\footnotetext{
${ }^{2}$ Vydaná zpráva zahrnuje souhrnné odhady daňových úlev za roky 2011 a 2012 u daně z přidané hodnoty, daně z př́ijmů fyzických osob a daně z př́ijmů právnických osob a dále seznam daňových úlev pro rok 2013 a změny v r. 2014-2015. Webový portál Ministerstva financí ČR [online]. [vid. 10. dubna 2015]. Dostupné z http://www.mfcr.cz/cs/verejny-sektor/hospodareni/rozpoctove-ramce-statisticke-informace/danove-ulevy
} 
V rámci bytové politiky a podpory bydlení lze odečíst od roku 1998 od základu daně výši úroků zaplacených ve zdaňovacím období z poskytnutého úvěru ze stavebního spoření nebo z hypotečního úvěru na bydlení. Úhrnná částka úroků, o které lze snížit základ daně ze všech úvěrů u poplatníků v téže společně hospodařící domácnosti nesmí překročit $300000 \mathrm{Kč}$.

Účelem odpočtu příspěvků na penzijní připojištění je snaha o aktivní zapojení poplatníkủ do vytváření vlastních finančních prostředků na starobní důchod. Od roku 2000 lze od základu daně odečíst výši plateb příspěvků na penzijní připojištění a penzijní pojištění, nebo doplňkové penzijní spoření, sníženou o 12000 Kč. Maximální částka, kterou lze takto odečíst za zdaňovací období celkem činí $12000 \mathrm{Kč}$. V rámci důchodové a sociální politiky lze také od roku 2001 odečíst výši pojistného, které je poplatníkem zaplaceno na soukromé životní pojištění. Maximální částka, kterou lze odečíst činí v úhrnu 12000 Kč.

Pro podporu zaměstnanecké politiky si mohou od roku 2004 členové odborových organizací, platících příspěvky odborové organizaci, která podle svých stanov obhajuje hospodářské a sociální zájmy zaměstnanců, od základu daně odečíst výši svých členských příspěvků, maximálně však do výše 3000 Kč. Dále lze od roku 2008 uplatnit výši úhrady za zkoušky ověřující výsledky dalšího vzdělávání až do výše 10000 Kč.

Od roku 2008 se upustilo od klouzavě progresivní sazby daně z př́ijmů fyzických osob. Zrušení daňové progrese a zavedení jednotné sazby daně ve výši $15 \%$ snížilo účinek odčitatelných položek používaných převážně střední třídou.

\section{Výsledky a diskuse}

Následující propočty sledují vývojové tendence využívání nezdanitelných částí základu daně, které vycházejí z podaných daňových přiznání fyzických osob. Vzhledem $\mathrm{k}$ tomu, že zaměstnanci nemusí podávat daňové přiznání a mohou daňové odpočty uplatnit $\mathrm{v}$ rámci ročního zúčtování daňových záloh u svých zaměstnavatelů, přičemž daňová správa nedisponuje jejich konkrétními údaji, mají omezenou vypovídací schopnost. Lze ale přijmout předpoklad, že mezi chováním poplatníků podávajících daňové přiznání a poplatníků, kteří daňové přiznání nepodávají, je stejné.

V jaké míře jsou nezdanitelné části základu daně využívány, je znázorněno na Obrázku 1. Nejvíce poplatníků svi̊j daňový základ snižuje o výši pojistného, zaplacené na soukromé životní pojištění. 
Obrázek 1: Počty daňových přiznání s uplatněním daňových úlev

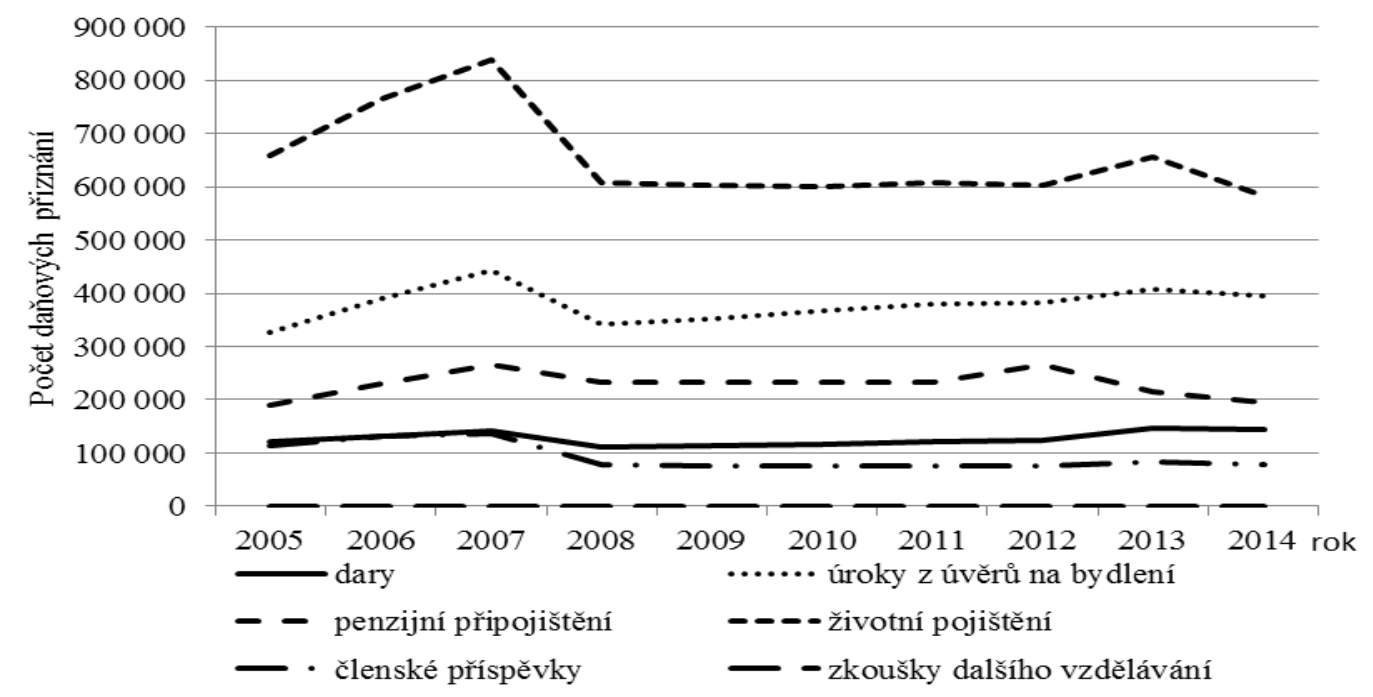

Zdroj: Webový portál Finanční správy ČR [online]. [vid. 14. července 2016]. Dostupné z: http://www.financnisprava.cz/cs/dane-a-pojistne/analyzy-a-statistiky/udaje-z-danovych-priznani. Vlastní zpracování.

Do roku 2007 tento počet měl vzrůstající tendenci. V roce 2008, ve kterém proběhla daňová reforma, kterou byla snížena sazba daně a výrazně navýšeny slevy na dani, využilo možnosti odpočtu na životní pojištění o 229 tis. poplatníků méně, což oproti předcházejícímu roku činí snížení o 27,3 \%. Další výraznější propad počtu poplatníků, využívajících odpočet na životní pojištění je v roce 2014. Toto snížení mohla způsobit legislativní změna, kterou byly upraveny podmínky pro možný odpočet na životní pojišsění. Od tohoto roku nelze uplatnit odpočet u smlouvy životního pojištění, které umožňují výběr naspořených peněz dřive než v 60-ti letech poplatníka.

Druhou nejvíce využívanou možností snížení daňového základu u fyzických osob jsou odpočty úroků. I v tomto prípadě dochází ke snížení počtu poplatníků, uplatňujících odpočet v roce 2008. Následně jejich počet pozvolně narůstá. Vzhledem ke snížení úrokových sazeb v tomto období lze vyvodit zvýšený zájem o hypoteční úvěry.

Na třetí pozici se nacházejí odpočty př́spěvků na důchodové pojištění a připojištění. V tomto př́padě v roce 2008 se počet poplatníkủ snížil o $12,3 \%$. Od roku 2013, kdy byla zavedena neúspěšná důchodová reforma, se počet poplatníků dále snižuje. V roce 2014 využilo možnosti odpočtu př́spěvku na důchodové pojištění jen 195 tis. poplatníků z celkového počtu 2123 tis. podaných daňových přiznání, což je $9,2 \%$ a to i přes to, že se k zatraktivnění systému podpory spoření na důchod neustále hledají nové cesty, a to jak z hlediska produktů ze strany daných společností, tak z hlediska účastníka a zájemce. Rovněž i ze strany státu je snaha otevř́í a nabídnout produkty co nejširšímu okruhu zájemců, což dokládá i připravovaná novela daňového zákona, která má mimo jiné zvýšit maximální limit odpočtu na penzijní připojištění na částku 24000 Kč. 
Obrázek 2: Využívání nezdanitelných částí daně k celkovému počtu podaných daňových přiznání $(\%)$

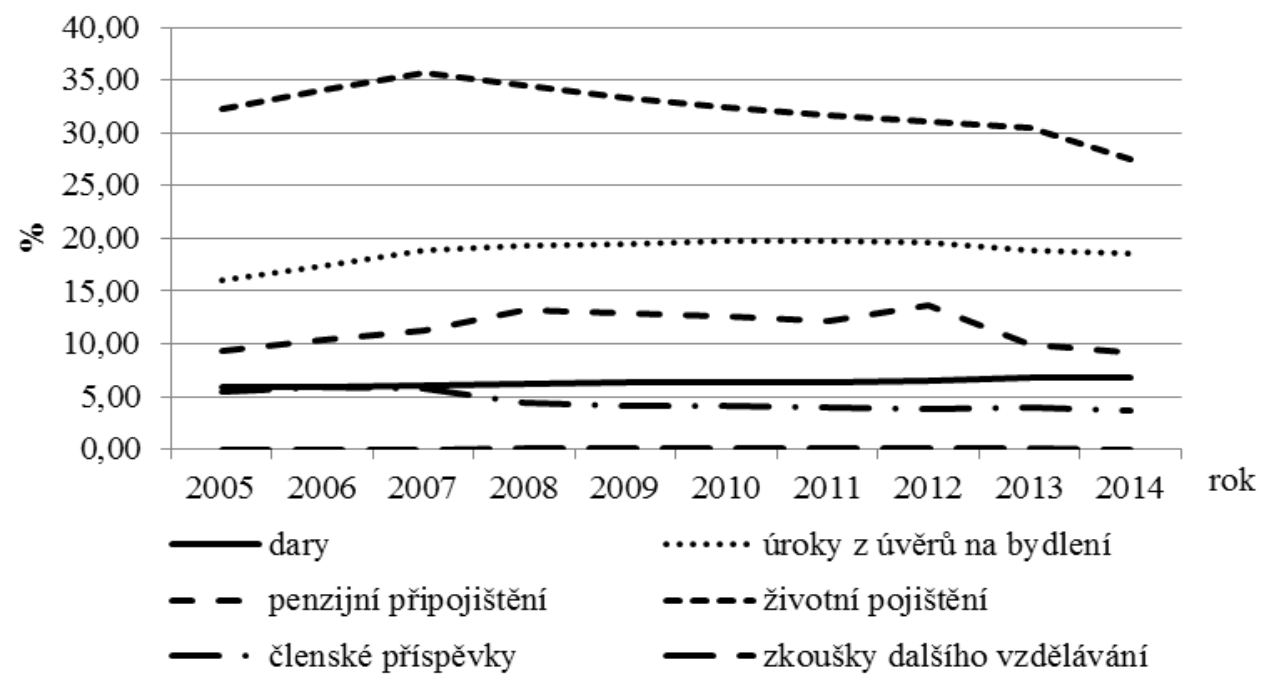

Zdroj: Webový portál Finanční správy ČR. [online] vid. 14. července 2016]. Dostupné z: http://www.financnisprava.cz/cs/dane-a-pojistne/analyzy-a-statistiky/udaje-z-danovych-priznani. Vlastní zpracování.

Jaké je procentuální využití k celkovému počtu podaných přiznání u všech nezdanitelných částí daně znázorňuje Obrázek 2. Počet poplatníků, kteří si uplatňují odpočty na poskytnuté dary, není v ČR př́liš vysoký a pohybuje se kolem $6 \%$ z celkového počtu podaných daňových přiznání. V posledních dvou sledovaných letech má ale mírně vzrůstající tendenci. V roce 2014 uplatnilo odpočty na dary téměř 145 tis. poplatníků. Pokud stát bude chtít docílit dlouhodobost a udržitelnost altruistického chování českých domácností a firem a trend vývoje poskytování darů potřebným se začal navyšovat, bude muset zvolit jiné prostředky, napřr. větší formu osvěty. Možnost odpočtu daru jako nezdanitelné části daně je nedostačující, nemá př́liš silný motivační vliv a nijak výrazně poplatníky neovlivňuje.

Odpočty na příspěvky zaplacené odborovým organizacím, jsou po propadu v roce 2008 uplatňovány po celé další období stabilním počtem poplatníků, který se pohybuje kolem $4 \% \mathrm{z}$ celkového počtu podaných daňových přiznání. Počet poplatníků uplatňujících odpočty na zkoušky dalšího vzdělávání je zanedbatelný.

Pokud se porovnávají celkové sumy daňových odpočtů fyzických osob, které podaly daňové přiznání, znázorněné na Obrázku 3, nejvyšší částky byly odečteny od daňového základu na úroky z úvěrů na bydlení. Během sledovaného období došlo k jejich navýšení o více než $100 \%$, a to z částky 7297 mil. Kč v roce 2005 na 16605 mil. Kč v roce 2013. Nejvíce využívané odpočty z životního pojištění byly uplatněny v maximální celkové částce 6022 mil. Kč a to $\mathrm{v}$ roce 2007 . Odpočty na důchodové pojištění v tomto roce byly také na maximu a činily celkem 2413 mil. Kč. U darů byla nejvyšší celková částka odpočtu daňovými poplatníky uplatněna v roce 2014, a to ve výši 1743 mil. Kč. Celkové odpočty na příspěvky odborovým organizacím činí v průměru 184 mil. Kč a odpočty na zkoušky dalšího vzdělávání, zavedené až v roce 2008, jsou v průměrné výši 2 mil. Kč. 
Obrázek 3: Celkové sumy nezdanitelných částí daně

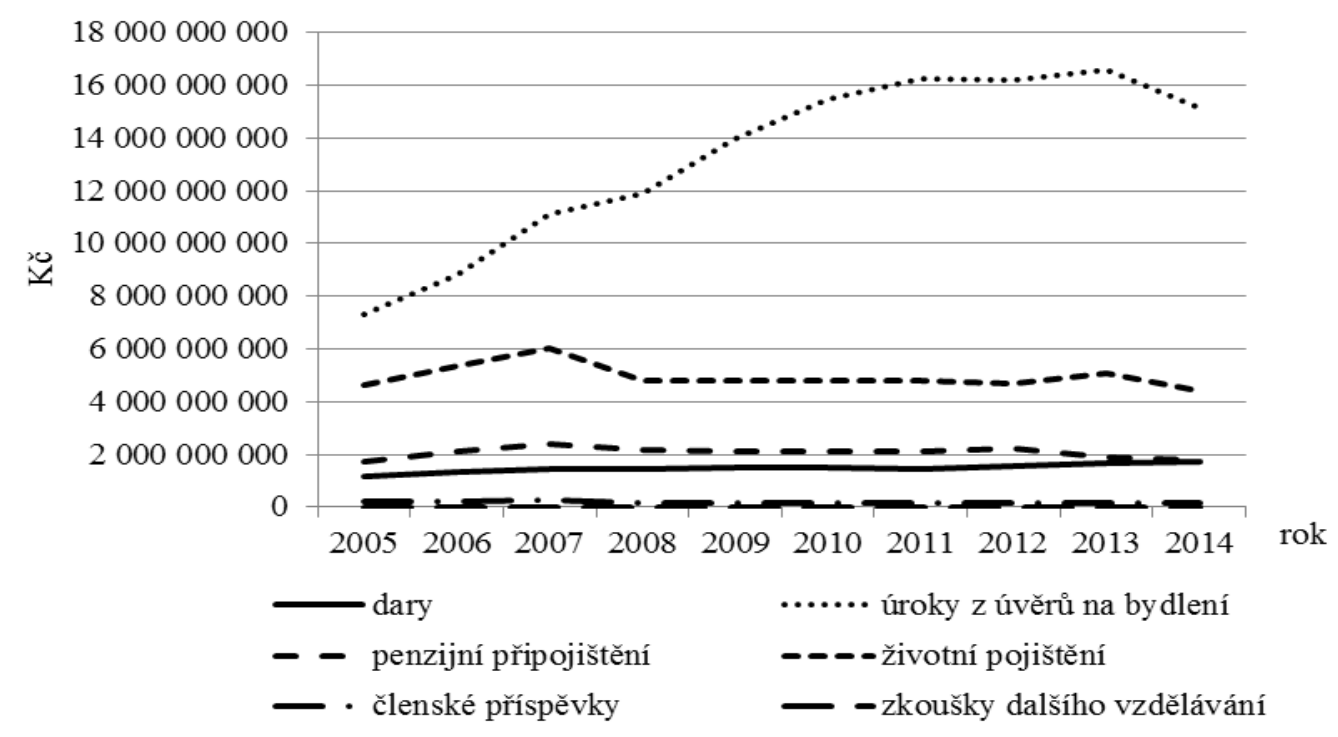

Zdroj: Webový portál Finanční správy ČR [online] [vid. 14. července 2016]. Dostupné z: http://www.financnisprava.cz/cs/dane-a-pojistne/analyzy-a-statistiky/udaje-z-danovych-priznani. Vlastní zpracování.

Průměrné částky daňových odpočtů, které byly daňovými poplatníky uplatněny, jsou uvedeny v Tabulce 1 a to podle vztahu:

$$
A T A=S T A / d
$$

kde STA je celková suma uplatněných nezdanitelných částí daně a $d$ je počet daňových přiznání, ve kterých byla nezdanitelná část daně uplatněna.

Nejvíce poplatníci snížili svůj daňový základ o zaplacené úroky z úvěrů. Nejvyšší uplatněná průměrná částka 42749 Kč z roku 2011 se ani zdaleka nepřibližuje k maximální možné částce odpočtů na úroky, která je 300 tis. Kč. Průměrné odpočty na penzijní připojištění jsou spíše vysoké, blížící se k maximální možné hranici 12 tis. Kč. Jestliže došlo vlivem důchodové reformy ke snížení počtu poplatníků po roce 2013, kteří uplatňují nezdanitelnou část ze základu daně na penzijní připojištění, pak na druhou stranu se dá říct, že poplatníci přispívající si na důchod navýšili své př́íspěvky. U odpočtů z životního pojištění jsou průměrné částky klesající. Dary fyzické osoby poskytli ve sledovaném období v rozmezí 9813 a 13106 Kč, přičemž nejvyšší průměrný dar připadá na rok 2009.

Tabulka 1: Průměrný odpočet nezdanitelných částí daně (Kč)

\begin{tabular}{|c|c|c|c|c|c|c|c|c|c|c|}
\hline & 2005 & 2006 & 2007 & 2008 & 2009 & 2010 & 2011 & 2012 & 2013 & 2014 \\
\hline dary & 9813 & 10123 & 10412 & 12884 & 13106 & 12896 & 12085 & 12581 & 11307 & 12028 \\
\hline úroky z úvěrů na bydlení & 22297 & 22626 & 25118 & 34733 & 39711 & 42352 & 42749 & 42371 & 40784 & 38304 \\
\hline penzijní připojištění & 9057 & 9032 & 9109 & 9302 & 9171 & 9162 & 9128 & 8464 & 8783 & 9183 \\
\hline Životní pojišstění & 7042 & 7017 & 7187 & 7894 & 7940 & 7954 & 7906 & 7770 & 7711 & 7596 \\
\hline členské příspěvky & 1737 & 1832 & 1915 & 2008 & 2023 & 2088 & 2128 & 2169 & 2151 & 2172 \\
\hline Zkoušky dalšího vzdělávání & 0 & 0 & 0 & 4347 & 4534 & 4817 & 4326 & 4279 & 4374 & 4477 \\
\hline
\end{tabular}

Zdroj: Vlastní zpracování.

Celkové sumy všech nezdanitelných částí daně, uplatněných na podaných daňových přiznáních fyzických osob, jsou uvedeny v Tabulce 2. Nejvyšší celkovou částku 25387 mil. Kč odečetli poplatníci od základu daně v roce 2013. Dopad na státní prŕijem z této částky může znamenat až 3808 mil. Kč. V tabulce je propočtena výše daně, o kterou byla celkově snížena daňová 
povinnost poplatníků před uplatněním slev na dani. Vzhledem ke složitosti výpočtu u progresivního zdanění je propočet proveden až od roku 2008, kdy byla zavedena jednotná sazba daně $15 \%$.

Tabulka 2: Suma nezdanitelných částí základu daně uplatněná v daňových přiznáních a propočtená výše daně (v tis. Kč)

\begin{tabular}{|l|r|r|r|r|r|r|r|}
\hline & \multicolumn{1}{|c|}{$\mathbf{2 0 0 8}$} & \multicolumn{1}{c|}{$\mathbf{2 0 0 9}$} & \multicolumn{1}{c|}{$\mathbf{2 0 1 0}$} & \multicolumn{1}{c|}{$\mathbf{2 0 1 1}$} & \multicolumn{1}{c|}{$\mathbf{2 0 1 2}$} & \multicolumn{1}{c|}{$\mathbf{2 0 1 3}$} & \multicolumn{2}{c|}{$\mathbf{2 0 1 4}$} \\
\hline suma nezdanitelných částí & 20431210 & 22554624 & 24088243 & 24820282 & 24860931 & 25387005 & 23259605 \\
\hline daň & 3064682 & 3383194 & 3613236 & 3723042 & 3729140 & 3808051 & 3488941 \\
\hline
\end{tabular}

Zdroj: Vlastní zpracování.

Vyjde-li se z předpokladu, že chování všech poplatníků daně z př́ijmů fyzických osob, zahrnující jak poplatníky podávající daňové přiznání, tak poplatníky, za něž podává roční vyúčtování daně zaměstnavatel je obdobné, lze jednoduchým propočtem odhadnout celkový dopad na veřejné finance podle následujícího vztahu:

$$
S T A=n . T A_{i}
$$

kde $n$ je celkový počet poplatníků daně z př́ijmů (ČSÚ, 2016) a $T A_{i}$ je průměrná nezdanitelná část daně na poplatníka.

Následující Tabulka 3 uvádí odhady jednotlivých nezdanitelných částí daně u všech plátců daně z př́jmů za výše zmíněného předpokladu a celkovou sumu nezdanitelných částí, uplatněných v letech 2008 - 2014. Dále je zde propočtená maximální výše daně, kterou by poplatníci mohli navíc odvést do státního rozpočtu za podmínky, že by jejich výsledná daňová povinnost byla vyšší než uplatněné daňové slevy.

Tabulka 3: Suma nezdanitelných částí daně všech poplatníků daně z př́ijmů a propočtená daň (v tis. Kč)

\begin{tabular}{|l|r|r|r|r|r|r|r|}
\hline & \multicolumn{1}{|c|}{$\mathbf{2 0 0 8}$} & \multicolumn{1}{|c|}{$\mathbf{2 0 0 9}$} & \multicolumn{1}{|c|}{$\mathbf{2 0 1 0}$} & \multicolumn{1}{|c|}{$\mathbf{2 0 1 1}$} & \multicolumn{1}{|c|}{$\mathbf{2 0 1 2}$} & \multicolumn{1}{|c|}{$\mathbf{2 0 1 3}$} & \multicolumn{2}{|c|}{$\mathbf{2 0 1 4}$} \\
\hline dary & 64453689 & 64669606 & 62999141 & 58882261 & 61523749 & 55824037 & 59829248 \\
\hline úroky z úvěrů na bydlení & 173753564 & 195944148 & 206899992 & 208290686 & 207199404 & 201356254 & 190537376 \\
\hline penzijní přiipojištění & 46535281 & 45251655 & 44757125 & 44477410 & 41390922 & 43360737 & 45679160 \\
\hline životní pojištění & 39491577 & 39176693 & 38858377 & 38522673 & 37995643 & 38069312 & 37784042 \\
\hline členské př́spěvky & 10047334 & 9980587 & 10200155 & 10369480 & 10604687 & 10619299 & 10806614 \\
\hline zkoušky dalšího vzdělávánín & 21743802 & 22374130 & 23530626 & 21078834 & 20922794 & 21596633 & 22268333 \\
\hline SUMA & 356025248 & 377396820 & 387245415 & 381621345 & 379637200 & 370826272 & 366904772 \\
\hline DAŇ & 53403787 & 56609523 & 58086812 & 57243202 & 56945580 & 55623941 & 55035716 \\
\hline
\end{tabular}

Zdroj: Vlastní zpracování.

Není ale korektní se domnívat, že tento odhad maximálních ušlých příjmů by v případě zrušení nezdanitelných částí daně skutečně tak vysoké částky do veřejných rozpočtů přinesl. Propočet nemůže brát $\mathrm{v}$ úvahu př́padné změny $\mathrm{v}$ chování poplatníků, kteří mohou své aktivity přenést do jiných oblastí.

\section{Závěr}

Nezdanitelné části základu daně v případě poplatníků fyzických osob snižují základ daně a tím vedou k nižšímu zdanění. Současně tak dochází ke snižování př́ijmů veřejného rozpočtu a je otázkou, do jaké míry důvody zavádění odpočtů převažují nad těmito ušlými př́íjmy. Nicméně daňové úlevy představují jeden z významných nástrojů daňové optimalizace (Alpanda, Zubairy 2016). 
Účinek nezdanitelných části základu daně v ČR byl výrazně snížen upuštěním od klouzavě progresivní sazby daně z př́jmů fyzických osob v roce 2008 a zavedením jednotné sazby daně ve výši $15 \%$. To dokládá i propad v počtech poplatníků, využívajících daňové odpočty. Jestliže daňový odpočet má podpořit dané veřejné politiky a usměrnit chování poplatníků žádoucím směrem, snížení daňové sazby či zrušení progresivní sazby daně jejich poslání značně redukuje. Rovněž v delším časovém období se vlivem inflace reálná hodnota výše daňových odpočtů snižuje.

Jak je patrné z propočtů, je docíleno zainteresování poplatníků s vyššími až nadstandardními př́ijmy, pro které mají daňové odpočty význam pro dosažení nižšího odvodu daně. V tomto kontextu pak daňové odpočty snižují redistribuční efekt daní a pro poplatníky s nízkými příjmy se tato forma daňové podpory stává neúčinnou. Český daňový systém disponuje i slevami na dani a daňovým zvýhodněním na děti, které má stoupající tendenci. Tento fakt má za následek, že se u méně př́jjmových skupin vlivem uplatnění slev na dani ztrácí relevantnost uplatnění daňové výhody u nezdanitelné částky snižující základ daně. Navíc poplatník s nízkým př́ijmem nemá finanční prostor pro spoření na penzijní připojištění, pořízení vlastního bydlení, či poskytování darů neziskovým organizacím.

Účinek daňových odpočtů je také významnou měrou snižován i jinými politickými rozhodnutími. Příkladem mohou být daňové odpočty na př́íspěvky na penzijní připojištění, u kterých po roce 2013 dochází k propadu v počtu poplatníků, využívajících odpočet na penzijní připojištění. Lze konstatovat, že nová důchodová reforma i přes navýšení státních příspěvků na penzijní připojištění, nepřinesla žádoucí efekt ve větším zapojení poplatníků do vlastního spoření na stárí. Totéž lze shledat i u daňového odpočtu na prríspěvky životního pojištění, kdy legislativní změna podmínek odpočtů na životní pojištění měla za následek pokles v počtu poplatníků, uplatňujících daňový odpočet u životního pojištění.

Využití daňové úlevy u darů u fyzických osob je poměrně stabilní. Tyto úlevy jsou pozitivním aspektem v daňovém právu, ale samy o sobě více finančních prostředků nestátním neziskovým organizacím nepřinesou. I přes navýšení maximální hranice pro odpočet darů v roce 2014 nemají silný vliv na motivaci k individuální angažovanosti. Nicméně mohou mít vliv na objem darů, zejména u movitějších individuálních dárců. (Janoušková, Kirschnerová 2016).

Výpočet výše ušlých př́ijmů státního rozpočtu vlivem daňových odpočti̊ komplikuje nedostupnost údajů o zaměstnancích. Finanční správa nedisponuje konkrétními daňovými položkami, protože povinností zaměstnavatelů je předkládat pouze souhrnné údaje o svých zaměstnancích. $Z$ tohoto důvodu je možné provést pouze odhad pravděpodobných částek.

Daně mohou mít negativní vliv na hospodářský růst, nebot' př́ímo zatěžuji aktivitu poplatníků. Proto je důležité zvážit, zda nastavení daňových odpočtů je v kontextu cílů daných veřejných politik. Je nezbytné znát jednotlivé faktory a aspekty, které ovlivňují solidaritu zdanění př́ijmů fyzických osob a jsou motivační pro daňové poplatníky.

V neposlední řadě je zapotřebí vzít do úvahy, že využitím alokační a stimulační funkce daní v souvislosti s danou veřejnou politikou, vznikají dodatečné administrativní náklady jak na straně poplatníka, tak i na straně správce daně a rostoucí složitost a komplikovanost daňového systému s sebou nese i zvýšenou možnost legálních i nelegálních daňových úniků. 


\section{Poděkování}

Tento příspěvek byl zpracován v rámci Studentské grantové soutěže Slezské univerzity v Opavě 2016, s názvem projektu Daňové úlevy fyzických osob jako součást podpory veřejných politik v podmínkách ČR, číslo projektu SGS 20/16.

\section{Literatura}

[1] ALPANDA, S. and S. ZUBAIRY, 2016. Housing and tax policy. In: Journal of money credit and banking. Hoboken: WILEY-BLACKWELL, 2016. Vol. 48, Issue 2-3, p. 485512, DOI: 10.1111/jmcb.12307. ISSN: 0022-2879.

[2] ALTSHULER, R. and R. DIETZ, 2011. Reconsidering tax expenditure estimation In: National Tax Journal, 2011 [online]. [vid. 25. července 2016]. Dostupné z: https://www.ntanet.org/NTJ/64/2/ntj-v64n02p459-89-reconsidering-tax-expenditureestimation.pdf. Part 2, Vol. 64, Issue 2, pp. $459-490$.

[3] BURMAN, L. E., 2013. Pathways to Tax Reform Revisited. In: Public Finance Review 41(6): 755-790. DOI: 10.1177/1091142113499400. ISSN: 10911421

[4] ČIŽÍK, V., 2008. Informační studie - Rovná daň v teorii a praxi. Web Ministerstva financí ČR [online]. [vid. 14. ledna 2015]. Dostupné z: http://www.mfcr.cz/cs/oministerstvu/odborne-studie-a-vyzkumy/2008/rovna-dan-v-teorii-a-praxi9473http://www.mfcr.cz.

[5] FARICY, C. and C. ELLIS, 2014. Public Attitudes Toward Social Spending in the United States: The Differences Between Direct Spending and Tax Expenditures. Political Behaviour. 36 (1), 53-76. ISSN 01909320. DOI 10.1007/S11109-013-9225-5

[6] HALL, R. E. and A. RABUSHKA, 2007. The Flat Tax: Updated Revised Edition. Stanford: Hoover Press. ISBN 978-0-8179-9311-5.

[7] FOOKES, C., 2009. Spending through the Tax System: Tax Expenditures. In: New Zealand Policy Perspectives Paper 09/01, 2009 [online]. [vid. 25. července 2016]. Dostupné z: http://www.treasury.govt.nz/publications/research-policy/ppp/2009/09-01.

[8] JAMES, S. and CH. NOBES, 1999. The Economics of Taxation: Principles, policy and Practice. Harlow: Financial Times Prentice Hall. ISBN 0-273-64630-3.

[9] JANOUŠKOVÁ, J., 2012. Osobní dưchodová daň. Daně a daňová politika. Karviná: Slezská univerzita v Opavě. ISBN 978-80-7248-698-4.

[10] JANOUŠKOVÁ, J. a P. KIRSCHNEROVÁ, 2015. Daňové úlevy fyzických osob jako jeden z aspekti̊ podpory filantropie v ČR. Acta Academica Karviniensia 4/2015. Karviná: Slezská univerzita v Opavě, Obchodně podnikatelská fakulta v Karviné, 2015. s. 28 - 40. ISSN: $1212-415 \mathrm{X}$

[11] JANOUŠKOVÁ, J. a P. KIRSCHNEROVÁ, 2016. Uplatněni daňového odečtu darů u fyzických osob v regionech ČR. In: Klímová, V., Žítek, V. (eds) XIX. Mezinárodní kolokvium o regionálních vědách. Sborník př́spěvků. Brno: Masarykova univerzita, 2016, p. 899-906. ISBN: 978-80-210-8273-1.

[12] JAREŠ, M., 2010. Výzkumná studie - Daňové úlevy v České republice 2010. Ministerstvo financí ČR [online]. [vid. 14. února 2015] Dostupné z: http://www.mfcr.cz/cs/oministerstvu/odborne-studie-a-vyzkumy/2010/danove-ulevy-v-ceske-republice-9442.

[13] KUBÁTOVÁ, K. a M. JAREŠ, 2011. Identifikace a kvantifikace daňových úlev v $\check{C} R$. Politická ekonomie. 4, 475-489. ISSN 0032-3233. 
[14] PECHMAN, J., 2001. Federal tax policy. Washington: Brookings Institution Press. ISBN 0-8157-6962-8.

[15] POLACKOVA BRIXI, H. and L. ZHICHENG, 2004. Tax Expenditures-Shedding Light on Government Spending Through the Tax System. Washington : The World Bank, 2004.

[16] SURREY, S., 1973. Pathways to tax reform: the concept of tax expenditures. Cambridge: Harvard University Press. ISBN 978-0-674-43650-3.

[17] WALKER, D., 2006. Government Performance and Accountability: Tax Expenditures Represent a Substantial Federal Commitment and Need to Be Reexamined. Washington: DIANE Publishing. ISBN 1-4223-0359-4.

[18] Webový portál ČSÚ. Statistiky zaměstnanosti [online]. [vid. 14. srpna 2016]. Dostupné z: https://vdb.czso.cz/vdbvo2/faces/cs/index.jsf?page=vystup-objekt\&pvo=ZAM02-

A\&skupId=446\&filtr=G F_M F_Z F_R T _P _S _null_null_\&katalog=30853\&Z=T\& $\mathrm{f}=\mathrm{TABULKA} \& \mathrm{c}=\mathrm{v} 3 \sim 8 \_\mathrm{RP} 2005 \& \& \mathrm{str}=\mathrm{v} 274$

[19] Webový portál Evropská unie: Eur - Lex [online]. [vid. 15. října 2016]. Dostupné z: http://eur-lex.europa.eu/legal-content/CS/TXT/?uri=CELEX:32011L0085

[20] Webový portál Finanční správy ČR. Analýzy a statistiky [online]. [vid. 14. července 2016]. Dostupné z: http://www.financnisprava.cz/cs/dane-a-pojistne/analyzy-a-statistiky/udajez-danovych-priznani

[21] Webový portál Ministerstva financí ČR. Zpráva o daňových úlevách v České republice za roky 2011-2015 [online]. [vid. 10. dubna 2015]. Dostupné z http://www.mfcr.cz/cs/verejny-sektor/hospodareni/rozpoctove-ramce-statistickeinformace/danove-ulevy 